\title{
PENGARUH BALIKAN (FEEDBACK)GURU DALAM PEMBELAJARAN TERHADAP MOTIVASI DAN HASIL BELAJAR PESERTA DIDIK (SUATU KAJIAN TEORITIS DAN EMPIRIK)
}

\author{
Sumarno \\ SMK Negeri 5 Malang, Jl. Ikan Piranha Atas Kota Malang \\ email:marnoguru@gmail.com
}

\begin{abstract}
Feedback in learning is defined as information that is communicated to students that aims to change the thinking or behavior to improve the learning process. Giving feedback by teachers in teaching is an important activity to improve their knowledge and acquisition capabilities, accomplishments, and motivate learners. The researchers recommend the characteristics of effective feedback in learning must be non-evaluative, supportive, timely, and specific. Feedback provided in the form of learning on the learner information in response to action learning activities that have been carried out. Feedback can be presented in various forms, for example in the form of verification of the accuracy of the answers, an explanation of the correct answer, instructions and examples as well as performed at any time during the learning process, such as it provides answers, or after a certain time lag. Effect of feedback in learning can be explained with reference to the learning theories, namely the theory of behaviorism, cognitivism, constructivism and learn some vital lessons theory of selfregulation.
\end{abstract}

Keyword:feedback, learning outcomes, learning theory

\begin{abstract}
Abstrak:Feedbackatau balikan dalam pembelajaran didefinisikan sebagai informasi yang dikomunikasikan kepada peserta didik yang bertujuan merubah pemikiran atau perilakunya untuk memperbaiki proses pembelajaran. Pemberianfeedback atau balikanoleh guru dalam pembelajaran merupakan kegiatan penting untuk memperbaiki pengetahuan, pemerolehan kemampuan, prestasi, dan memotivasi belajar peserta didik.Para peneliti merekomendasikan karateristik feedback yang efektifuntukpembelajaran haruslah bersifat non evaluatif, suportif, tepat waktu, dan spesifik.Feedback pembelajaran diberikan berupa informasi pada peserta didik sebagai respontindakan kegiatan belajar yang telah dilakukan.Feedbackdapat disajikan dalam berbagai macam bentuk misalnya berupa verifikasi akurasi jawaban, penjelasan tentang jawaban yang benar, petunjuk dan contoh serta dilakukan kapanpun selama proses pembelajaran, misalnya setelah diberikannya jawaban, atau setelah jeda waktu tertentu. Pengaruh feedback dalam pembelajaran dapat dijelaskan dengan mengacu pada teori-teori belajar yaitu teori behaviourisme, kognitivisme, konstruktivisme dan teori belajar regulasi diri.
\end{abstract}

Kata Kunci:umpan balik, hasil belajar, teoribelajar

Artikel ini merupakan hasil kajian jurnal-jurnalriset tentang pengaruh balikan (feedback) hasil tugas atau evaluasi yang diberikan guru kepada peserta didik terhadap hasil pembelajaran. Feedback atau balikan adalah informasi yang dikomunikasikan pada siswa dan ditujukan untuk merubah pemikiran atau perilakunya untuk memperbaiki proses pembelajaran. Berdasarkan hasil penelitian tentang feedback atau balikan dalam pembelajaran secara umumdisimpulkan sebagaikegiatan penting untuk memperbaiki perolehan pengetahuan dan kemampuan, demikian kesimpulan hasil penelitian: Azevedo, dan Bernard, 1995; Bangert-Drowns, Kuli, Kulik, Morgan, 1991; Moreno, 2004; Pridemore dan Klein, 1995. Selain pengaruhnya pada prestasi, feedbackatau balikan juga sebagai faktor penting untuk memotivasi belajar, demikian kesimpulan hasil penelitian: Lepper dan Chabay, 
1985; Narciss, dan Huth, 2004 (dalam Shute Valerie, J. 2008. 153).

Tujuan dari artikel ini adalah menyajikan temuan dari kajian literatur tentang pentingnya feedback agar semakin dapat memahami sifat, fungsi, dan hubungannya dengan pembelajaran sertamenerapkan temuan-temuan dari kajian pustaka untuk menciptakan strategi yang terkait dengan balikan (feedback). Tujuan lain yang ingin dicapai adalah dapat mengidentifikasi karakteristik balikan tugas atau evaluasi yang efektif dan efisien untuk memperbaiki kualitas pembelajaran, dan menentukan dalam kondisi apa, dukungan pembelajaran tersebut bisa diberikan.

Subyek sasaran artikel ini adalah para pendidik, yang terus berusaha untuk meningkatkan kualitas pembelajaran di kelas dengan menggunakan balikan yang dirancang dengan baik, para psikolog kognitif dan desainer system pembelajaran yang tertarik untuk meneliti dan mengembangkan lingkungan belajar yang lebih efektif, para mahasiswa yang ingin melakukan penelitian dan pihak-pihak lain yang tertarik meneliti kekuatan feedback untuk mendukung proses belajar mengajar di kelas, di tempat kerja atau bahkan di rumah.

Artikel ini dimulai dengan pembahasan balikan (feedback) dalam perspektif teori-teori belajar yaitu teori behaviourisme, kognitifisme, konstruktivisme dan teori regulasi diri. Selanjutnya disajikan uraian pengaruh feedback pada pembelajaran, strategi feedback efektif untuk pembelajaran, dan ringkasan hasil penelitian berkaitan dengan feedback dan hasil belajar kemudian diakhiri dengan kesimpulan.

\section{FEEDBACK DALAM PERSPEKTIF TEORI-TEORI BELAJAR}

Feedback atau balikanpada artikel ini didefinisikan sebagai informasi yang dikomunikasikan kepada peserta didik dan ditujukan untuk memodifikasi pemikiran atau perilaku peserta didik agar dapat memperbaiki kualitas pembelajaran(ShuteValerie.J.2008:154). Tujuan utama pemberian feedback atau balikan adalah meningkatkan pengetahuan, keterampilan dan pemahaman siswa tentang keterampilan umum atau bidang tertentu (misalnya pemecahan masalah), dan berbagai macam jenis feedback bisa digunakan untuk tujuan lain, misalnya feedback respons khusus, diarahkan pada tujuan melakukan perbaikan tugas tertentu dan langsung diberikan.

Menurut Black dan William (1998), ada dua fungsi utama dari feedback: yaitu fungsi direktif dan fasilitatif. Feedback direktif adalah balikan yang memberitahu peserta didikapa yang harus diperbaiki atau direvisi. Balikanjenis direktif cenderung lebih spesifik jika dibandingkan dengan feedback fasilitatif yang memberikan komentar dan saran untuk membantu siswa ketika melakukan revisi dan konseptualisasi. Bagaimanakah pengaruh feedback guru dalam proses pembelajaran terhadap motivasi dan hasil belajar? Pertanyaan tersebut dapat dijawab dengan pendekatan teori-teori belajar yaitu teori behaviourisme, kognitivisme, konstruktivisme dan teori belajar regulasi diri. Adapun secara empiris pengaruh feedback dapat ditunjukan dengan temuan-temuan hasil riset yang telah dipublikasikan.

\section{Feedback dalam Perspektif Teori Behaviourisme.}

Berdasarkan sudut pandang behaviorist, belajar dipandang sebagai sebuah pengkondisian dimana perilaku yang diikuti dengan penguat ( $r e$ inforce) akanmengalami peningkatan frekuensi atau probabilitasnya (Operant Conditioning dari Skinner). Belajar dianggap sebagai sebuah proses penguatan pengetahuan yang didapat dalam sebuah pola hierarkis yang berurutan dan tugas belajar bisa direncanakan, diorganisir, dan diprogram dengan tujuan tertentu. Tugas belajar dianalisis dengan tujuan untuk mengidentifikasi komponen-komponen yang harus dikuasai untuk bisa menyelesaikan tugas tersebut dan urutan belajar yang paling tepat dirumuskan dengan berdasarkan pada hasil belajar yang bisa diamati.

Feedback dipandang sebagai penguatan, dengan tujuan untuk bisa membantu pebelajar berkembang dari penguasaan performa penyelesaian tugas-tugas sederhana ke tugastugas yang kompleks sifatnya.Dasar pemikiran dari kaum behaviorist tersebut bisa dilihat dengan jelas, yaitu adanya feedbackyang berasal dari sumber eksternal untuk bisa menyesuaikan hasil belajar eksternal dengan performa pebelajar untuk tugas-tugas tertentu.Pandangan umum feedbackdianggap sebagai motivator atau insentif untuk meningkatkan respons dan/atau akurasi (Kulhavy dan Wager, 1993).Feedback dalam perspektif teori behaviourisme digambarkan pada gambar 1.: 
Gambar 1. Feedback dalam perspektif teori behaviorisme

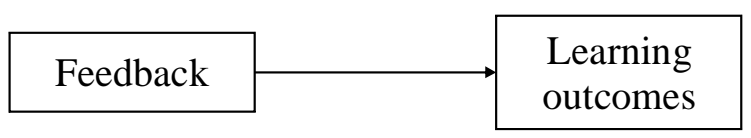

Fig. 1. The feedback model for behaviourism

\section{(Sumber:Marieke Thurlings, Marjan Vermeulen, Theo Bastiaens, Sjef Stijnen. 2013. Understanding feedback: A learn- ing theory perspective ,Educational Research Review 9 ,1-15).}

Feedback sebagai penguatsangat berguna bagi pebelajar level awal, tetapi efeknya sangat terbatas dan kadang-kadang malah membingungkan (Kulhavy dan Wager, 1993). Fokus pada insentif bisa mengalihkan perhatian pebelajar dari isi feedback dan mengakibatkan feedback tidak bisa ditafsirkan secara menyeluruh untuk pembelajaran (Kulhavy dan Wager, 1993). Anderson dan koleganya (1972) menemukan bahwa siswa biasanya mengabaikan feedback jika jawaban sudah ada di tugas-tugas pembelajaran dan ketika feedback diberikan sebelum tugas diselesaikan, siswa cenderung menyalin jawaban mereka dari feedback dan bukan dari hasil pengolahan informasi dari feedback tersebut secara bermakna.Temuan ini menunjukkan pentingnya pemberian feedback sebagai sebuah "konsekwensi" performa dan tidak boleh diberikan sebelum selesainya tugas belajar.

Pandangan yang menyatakan bahwa feedback berfungsi sebagai motivator atau insentif untuk pembelajaran masih tetap berlaku di kelaskelas sekarang ini, tetapi muncul kerancuan untuk membedakan antara pujian dan balikan yang terkait dengan isi pembelajaran (Hattie dan Timperley, 2007).Deci, Koester dan Ryan (1999) menemukan bahwa ketika guru memberikan penghargaan dalam bentuk konkrit sebagai sebuah feedback, maka motivasi intrinsik akan tereduksi secara signifikan dan siswa enggan untuk memotivasi atau mengatur diri sendiri. Feedback sebagai reward ekstrinsik seringkali mendorong siswa untuk lebih mementingkan insentif, yang akhirnya menyebabkan semakin tingginya intensitas evaluasi dan kompetisi dan bukan tingginya keterlibatan dalam pembelajaran.

\section{Feedback dalam Perspektif Teori Kognitivisme.}

Teori kognitivisme disebut juga teori dengan sudut pandang pengolahan informasi.Karakteristik penting dari teori pengolahan informasi adalah bahwa teori-teori tersebut mengakui kemampuan kognitif individu untuk mengunakan informasi secara aktif ketika terlibat dalam belajar.Ini menunjukkan bahwa feedback berfungsi tidak hanya untuk memperkuat jawaban yang benar tetapi juga menjadi informasi korektif untuk membantu pebelajar mengoreksi kesalahan yang mereka lakukan.Pendapat tentang feedback sebagai informasi ini menyatakan bahwa koreksi dan analisis kesalahan adalah menjadi komponen penting dalam belajar dan feedback berfungsi sebagai verifikasi atas kepastian respons atau tingkat kepastian jawaban dari pebelajar (Kulhavy dan Stock, 1989).Sebagai contoh, Model Respons dari Kulhavy dan Stock (1989) menunjukkan bahwa pesan balikan pembelajaran terdiri dari dua komponen yaitu verifikasi dan elaborasi. Verifikasi adalah sebuah penilaian dikotomis yang menunjukkan bahwa sebuah respons dianggap benar atau salah.Elaborasi adalah komponen pesan umpan balik, yang berisi informasi yang relevan untuk membantu pebelajar mengoreksi kesalahan. Hubungan feedback dengan pembelajaran dalam perspektif teori kognitif digambarkan pada gambar 2.

Gambar 2. Hubungan feedback dengan pembelajaran dalam perspektif teori kognitif.

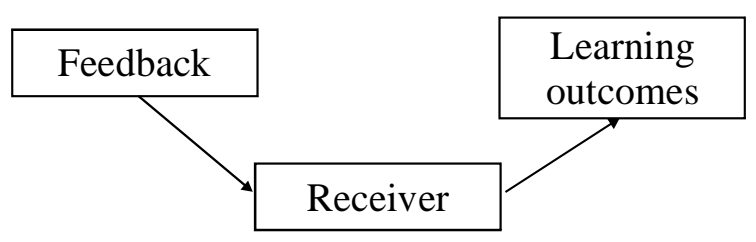

Fig. 1. The feedback model for cognitivism.

(Sumber : Marieke Thurlings, Marjan Vermeulen, Theo Bastiaens, Sjef Stijnen, 2013. Understanding feedback: A learning theory perspective, Educational Research Review 9.1-15).

Dalam perspektif ini, proses feedback terdiri dari tiga siklus, dimana masing-masing siklus mencakup stimulus eksternal, perbandingan input dengan standar referensi dan diikuti dengan 
respons. Siklus pertama menggambarkan pebelajar sebagai pihak yang membandingkan tuntutan tugas dengan pengalaman berikutnya dan mengevaluasi kemungkinan-kemungkinan respons yang ada.Siklus kedua mencakup pengolahan umpan balik oleh pebelajar.Disini, tingkat kepastian jawaban pebelajar dianggap terkait dengan perbedaan antara stimulus yang diterima dan hasilhasil yang diperoleh sesuai dengan standar referensi yang ada. Siklus tiga mencakup situasi dimana pebelajar memberikan respons kepada tugas yang sama setelah mengolah balikan dan mengarah munculnya jawaban yang tepat (Kulhavy, dkk, 1990).

Perpspektif lain yang menggunakan sudut pandang pengolahan informasi adalah teori intervensi feedbackoleh Kluger dan DeNisi (1996). Teori ini menyatakan bahwa intervensi feedback yang memfokuskan pebelajar pada tugas belajar akan menciptakan hasil belajar yang lebih bagus daripada feedback yang terfokus pada diri sendiri. Teori tersebut juga menyatakan bahwa jika feedback berpatokan padanorma yang membandingkan performa individu dengan individu lain yang lebih jelek bisa menyebabkan rendahnya kecapakan melakukan sesuatu, maka juga akan menurunkan harapan akan kinerja di masa mendatang dan menurunkan motivasi untuk tugastugas di masa mendatang.

\section{Feedback dalamPerspektif Teori Konstruktivisme.}

Konstruktivisme mempostulasikan bahwa pebelajar mampu secara aktif mengkonstruksi realitas atau pengetahuan mereka berdasarkan pengalaman awal, struktur mental dan keyakinan mereka.Ini meletakkan konstruktivisme sebagai sebuah teori belajar dan bukan teori mengajar (Bereiter, 2002; Hattie, 2009).Berbeda dengan behaviorisme yang memandang pengetahuan sebagai sebagai sebuah hal yang terpisah dari pebelajar, konstruktivisme memandang pengetahuan sebagai sebuah hal yang dikonstruksi oleh pebelajar ketika mereka berusaha memahami pengalaman-pengalaman mereka. Teori konstruktivist memandang bahwa pebelajar bukanlah sebuah wadah kosong yang perlu diisi, tetapi seorang yang aktif dalam proses penciptaan makna. Proses konstruktif mengharuskan pebelajar membentuk, mengelaborasikan, dan menguji struktur mental sampai diperoleh struktur mental yang memuaskan, dan terus mengalami perubahan ketika pengalaman pebelajar berbenturan dengan informasi baru yang akhirnya memicu terjadinya proses restrukturisasi baru. Feedback dalam pandangan konstruktivisme digambarkan pada gambar 3

Gambar 3. Feedback dalam pandangan konstruktivisme

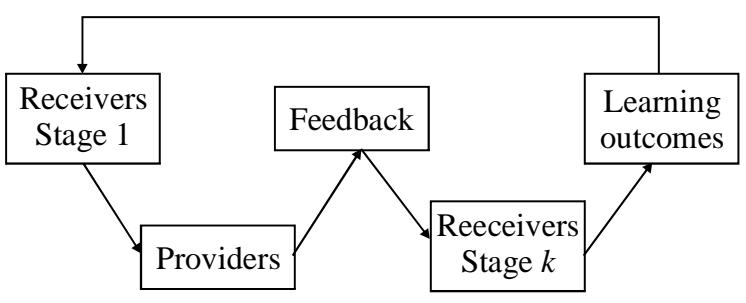

Fig. 3. The feedback model for meta cognitivism and model constructivism

(Sumber:Marieke Thurlings, Marjan Vermeulen, Theo Bastiaens, Sjef Stijnen, 2013. Understanding feedback:A learning theory perspective,Educational Research Review 9 , 1-15)

Penelitian yang dilakukan oleh Villamis dan de Guerrero (2006) memberikan beberapa pemahaman tentang feedback dalam konteks sosiobudaya. Melalui penelitian tentang feedback dari rekan sebaya, mereka menemukan bahwa perkembangan penguasaan bahasa kedua bisa ditingkatkan, yaitu ketika membahas tentang menulis dan merevisi bersama-sama dengan rekan. Villamil dan Guerrero menganalis interaksiinteraksi tersebut dan menemukan bahwa rekan sebaya tersebut ada regulasi diri dan memiliki kontrol yang sama, serta level empathy yang sama ketika menyimak komentar dari partnernya. Kemudian mereka bisa mendiskusikan masalahmasalah tekstual, menguasai kompetensi strategi menganalisis teks, memahami audien, dan mengembangkan regulasi diri untuk tulisan mereka. Walaupun penelitian tersebut mengakui manfaat dari interaksi sebaya dalam belajar, tetapi peneliti mencatat adanya keharusan mempersiapkan dan menginstruksikan pebelajar untuk melakukan perilaku-perilaku yang diharapkan seperti misalnya mempertahankan keterlibatan kognitif mutual dan meminimalkan perilaku-perilaku negatif yang bisa menghambat proses belajar kolaboratif. Peneliti 
merekomendasikan agar pendidik menyadari perilaku strategis dari pebelajar yang bisa mempengaruhi keberhasilan proses belajar ketika diberikan balikan dari rekan sebaya dan pendidik juga harus menyesuaikan diri dengan konteks sosiobudaya pebelajar dan latar belakangnya untuk meningkatkan proses belajar kolaboratif di kelas.

\section{Feedback dalam Perspektif Teori Regulasi Diri}

Feedback sebagai regulasi diri memberikan penekanan pada pentingnya interaksi antara informasi feedback dan penerima dan juga memberikan penekanan pada keterlibatan aktif pebelajar untuk mencari petunjuk-petunjuk dan memonitor serta mengevaluasi performa mereka sendiri. Buttler dan Winnie (dalam Thurling, M.2013:4)) mempostulasikan "beberapa jenis feedback yang mendukung keterlibatan regulasi diri dalam tugas yaitu dengan meningkatkan kalibrasi pebelajar". Kalibrasi menggambarkan sebuah "asosiasi akurat antara petunjuk dan prestasi" oleh pebelajar dan pebelajar disebut terkalibrasi dengan baik ketika dia mampu "mengatur dirinya sendiri dengan cara menyesuaikan pendekatan-pendekatan yang ada dengan berasarkan pada pemahaman akan petunjuk-petunjuk tugas yang terkait dengan prestasi”. Mengutip penelitian yang dilakukan oleh Balzer dkk (1989), Buttler dan Winnie menyatakan bahwa feedback kognitif bisa meningkatkan kalibrasi pebelajar dengan cara memonitor petunjuk-petunjuk seperti misalnya karakteristik tugas atau aktifitas kognitif, dan itu menjadi bagian penting dari regulasi diri.

Buttler dan Winnie (1995) lebih jauh menegaskan bahwa "keyakinan pebelajar tentang belajar akan mempengaruhi regulasi diri mereka yaitu ketika keyakinan tersebut mempengaruhi karakteristik dan interpretasi umpan balik". Berdasarkan dua penelitian lain yaitu penelitian tentang pandangan epistemologis tentang pebelajar oleh Chinn dan Brewer (1993) yang menyatakan bahwa pebelajar memberikan respons terhadap informasi yang ganjil, Buttler dan Winnie (1995) menyimpulkan bahwa pengetahuan awal, keyakinan dan pemikiran pebelajar berfungsi sebagai saringan untuk mengurangi efek feedback eksternal dan juga internal. Penurunan efek tersebut kemudian akan mempengaruhi monitoring keterlibatan tugas dan kemajuan pelaksanaan tugas oleh pebelajar, dan itu menjadi bagian yang tidak terpisahkan dari proses belajar dengan regulasi diri. Penekanan pada peran monitoring dan feedback dalam kerangka belajar regulasi diri memperluas konsepsi kaum obyektivist tentang feedback dan pengolahan informasi, serta mampu "mengintegrasikan pebelajar, regulasi diri, feedback dan konstruksi pengetahuan". Sintesis ini menampakanadanya pengakuan bahwa pebelajar bukanlah penerima feedback yang pasif tetapi mereka secara aktif menafsirkan informasi feedback melalui proses regulasi diri dan mereka memiliki kapasitas untuk bertanggung jawab atas proses belajar mereka sendiri.

\section{PENGARUH PEMBELAJARAN \\ FEEDBACKPADA}

Pengaruh pemberian feedback tidak bersifat umum tetapi hanya muncul dalam seting situasi tertentu; misalnya, jumlah waktu yang dibutuhkan untuk menghilangkan kesenjangan antara kenyataan dan harapan dengan bantuan feedback eksternal sangat bergantung pada (1) karakteristik individual dari siswa; (2) kualitas komponen umpan balik eksternal; (3) jenis, kompleksitas, dan kesulitan tugas; dan (4) jenis kesalahan. Untuk siswa yang pandai, feedback hasil pengetahuan saja sudah cukup untuk bisa menghasilkan jawaban yang benar di kemudian hari.Pada siswa dengan tingkat keterampilan yang rendah, untuk tugas yang sangat sulit, maka pemberian umpan balik tutorial informative tidak memadai untuk menguasai persyaratan yang rumit.

Efek berbagai macam feedback juga sangat bergantung pada bagaimana siswa mengolah dan menginterpretasikan informasi yang disediakan.Selain persyaratan kognitif (misalya pengetahuan awal, pengetahuan strategis), faktorfaktor motivasional seperti misalnya cakapan diri, nilai-nilai tugas dan faktor metakognitif individual seperti misalnya monitoring strategi dan kompetensi juga memiliki peran penting.Untuk menarik kesimpulan tentang efek berbagai jenis umpan balik tersebut, maka harus dilakukan pengontrolan bukan hanya pada factor motivasional dan metakognitif tetapi juga pada bagaimaana individu memproses feedback.

Feedback eksternal bisa menyebabkan perubahan yang terjadi (1) selama perlakuan, (2) segera setelah perlakuan, atau (3) lama setelah perlakuan; jadi, mengevaluasi efek berbagai 


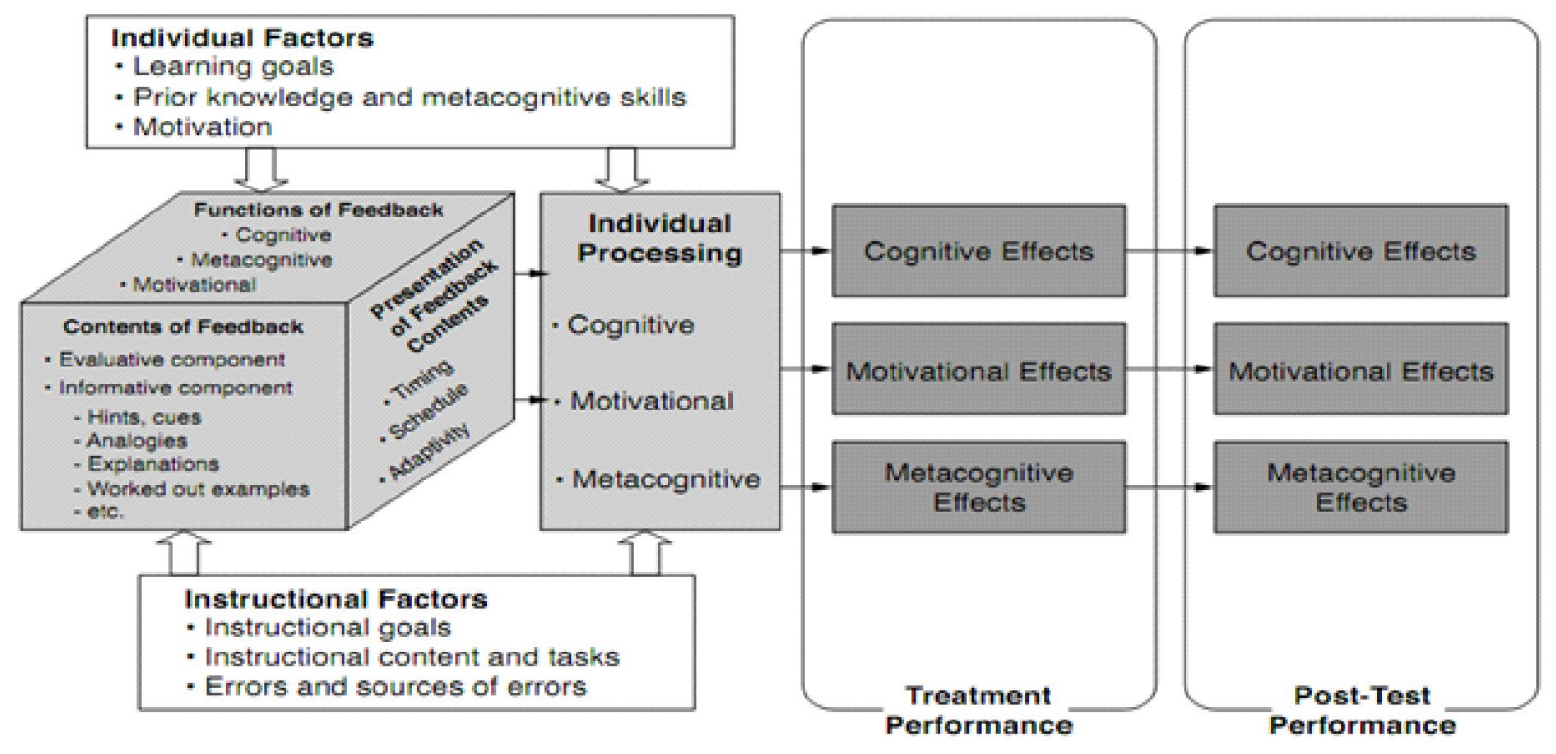

Gambar 4. Variebel yang berhubungan dengan berbagai efek berbagai jenis feedbeack eksternal. (Sumber: Narciss, S . 2006. Summary of factorsand effects of external feedback.Informative Tutoring Feedback, Waxmann, Münster).

macam strategi feedback mengharuskan kita untuk mengumpulkan data selama dan setelah perlakuan (Phye, 1991, 2001; Phye dan Sanders, 1994). Ketika meneliti efek berbagai jenis tipe atau strategi feedback eksternal, maka sudah tidak penting untuk menanyakan jenis umpan balik mana yang terbaik, tetapi yang harus dijawab adalah pertanyaan berikut:1) dalam kondisi situasional dan individual apa komponen atau strategi feedback memiliki nilai informasi yang tinggi bagi siswa?Dibawah kondisi situasional dan individual tersebut, efek kognitif, metakognitif dan motivasional apa yang ditimbulkan oleh komponen dan strategi feedback?Apa efek yang diharapkan muncul dan berapa lama ekspektasi durasinya? Skema berikut menyajikan ringkasan variablevariabel yang terkait dengan efek berbagai jenis feedback eksternal.

\section{STRATEGI FEEDBACK UNTUK PEMBELAJARAN}

EFEKTIF

Ada beberapa strategi yang bisa digunakan oleh guru untuk mereduksi kesenjangan antara kinerja aktual dengan yang diharapkan. Misalnya, dengan metode pemberian sasaran yang spesifik dan menantang. Sasaran yang spesifik adalah lebih efektif daripada sasaran yang umum dan tidak spesifik, khususnya karena sasaran memfokuskan perhatian siswa dan feedback bisa menjadi lebih terarah (Locke dan Latham,1984). Sasaran dan feedback juga bisa berisi informasi tentang kreteria keberhasilan untuk mencapainya.

Gurudapat menggunakan strategi dengan membantu peserta didik mengklarifikasi sebuah tujuan, meningkatkan komitmen atau meningkatkan usaha untuk meraihnya melalui pemberian feedback. Sasaran juga bisa dibuat menjadi lebih mudah untuk dikelola dengan cara mempersempit rentangan hipotesis yang ada (Sweller, 1990). Secara lebih umum, guru bisa menciptakan sebuah lingkungan belajar dimana siswa mengembangkan regulasi diri dan keterampilan mendeteksi kesalahan (Hattie, Biggs dan Purdie, 1996).

Bagaimana feedback atau balikan guru memberikan kontribusi pada proses-proses pembelajaran sangat bergantung pada fokus balikan dan tingkatan yang dituju.Konsep strategi pemberian feedback yang efektif dalam meningkatkan pembelajaran menurut John Hattie and Helen Timperley, (2007) diskemakan seperti pada gambar 5 .

\section{HASIL PENELITIAN FEEDBACK PEMBELAJARAN}

Hattie (1999) melaporkan sebuah sintesis yang dilakukan terhadap lebih dari 500 meta analisis, melibatkan 450.000 efek ukuran dari 


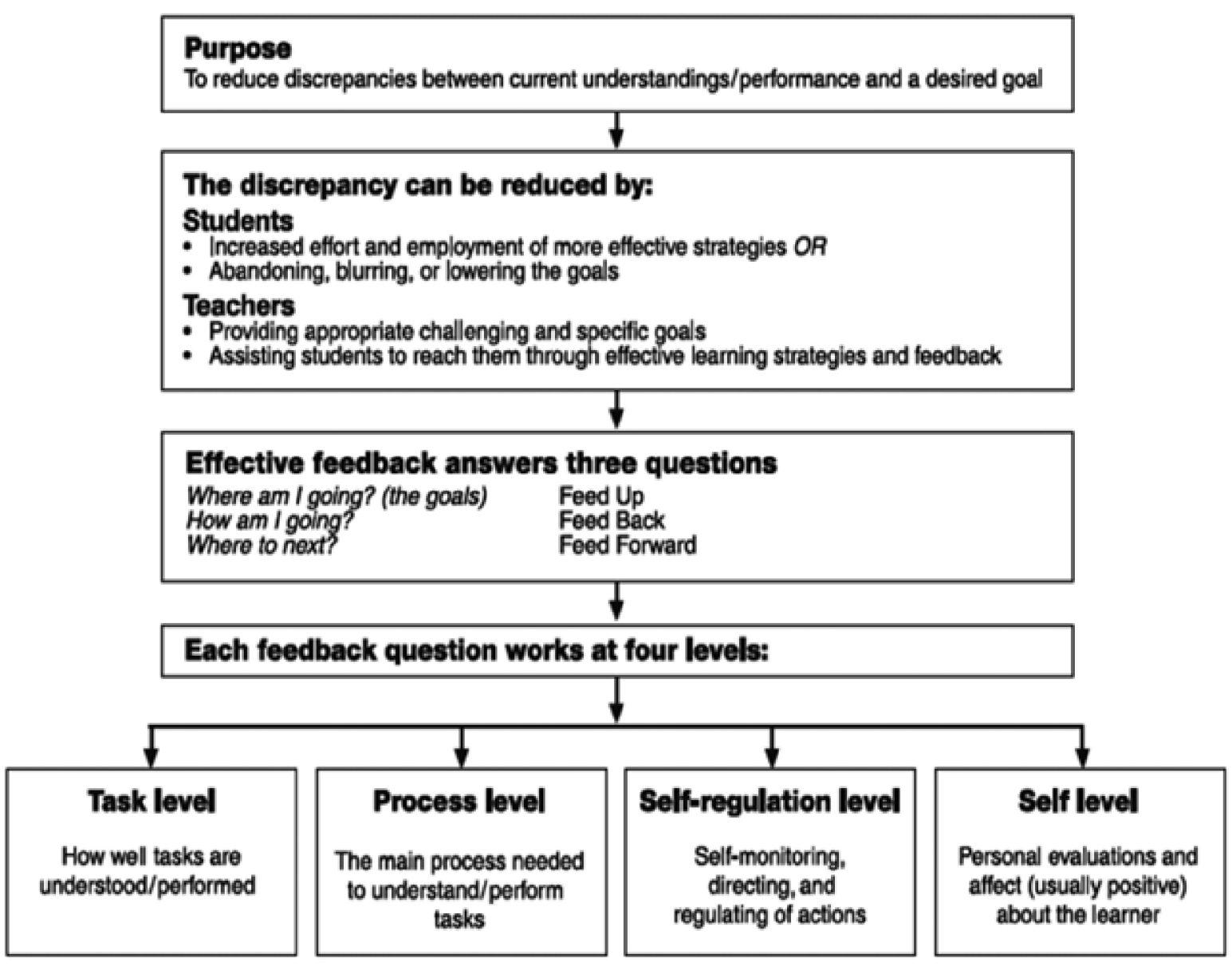

Gambar 5. Strategi pemberian umpan balik yang dapat meningkatkan pembelajaran. (John Hattie and Helen Timperley, 2007. The Power of Feedback, Review of Educational Research, Vol. 77, No. 1, pp. 81-112).

180.000 penelitian, dimana siswa yang terlibat didalamnya kira-kira 20 sampai 30 juta siswa, dan meneliti tentang berbagai macam aspek yang mempengaruhi prestasi siswa. Analisis ini meneliti lebih dari 100 faktor yang mempengaruhi prestasi pendidikan dan mencakup berbagai macam aspek yang diidentifikasi, misalnya atribut sekolah, rumah, siswa, guru dan kurikulum. Rata-rata efek atau efek tipikal yang ditimbulkan oleh sekolah adalah $0.40(\mathrm{SE}=0.05)$ dan ini menjadi figur patok duga (benchmark) atau "standar" yang bisa kita gunakan untuk menilai berbagai macam pengaruh pada prestasi, misalnya balikan atau feedback. Ringkasan efek ukuran dari 12 meta analisis yang menilai pengaruh feedback:

Paling tidak ada 12 meta analisis yang memasukkan informasi spesifik tentang feedback dalam kelas.Meta analisis tersebut mencakup 196 penelitian dan 6972 efek ukuran.Rata-rata efek ukuran yang ada adalah 0.79 (dua kali efek ukuran). Terkait dengan rata-rata 0.79 ini, maka dari sintesis yang dilakukan oleh Hattie, kita bisa mengetahui bahwa ia menempati peringkat 5 besar dari 10 pengaruh terbesar pada prestasi, bersamasama dengan pembelajaran langsung (0.93), pengajaran resiprokal (0.86), kemampuan kognitif awal siswa $(0,71)$ dan juga bisa dibedakan dengan pengaruh lainnya misalnya akselerasi (0.47), pengaruh sosioekonomi $(0,44)$, pekerjaan rumah (0.41), penggunaan kalkulator $(0.24)$, pengurangan ukuran kelas (0.12), dan retensi satu tahun ke belakang (-0.12). jelas, bahwa feedback sangatlah berpengaruh.

Efek ukuran yang ada dalam meta analisis feedback menunjukkan adanya variabilitas yang tinggi, dan itu menunjukkan bahwa ada beberapa feedback yang lebih kuat daripada yang lain. Penelitian-penelitian yang menunjukkan ukuran efek tertinggi tersebut mencakup siswa yang menerima feedback tentang sebuah tugas dan bagaimana melakukannya dengan lebih efektif.Efek ukuran yang lebih rendah adalah 
Tabel 1 :HasilPenelitian Efek Feedback Pada pembelajaran

(John Hattie and Helen Timperley. 2007.The Power of Feedback, Review of Educational Research , Vol. 77, No. 1, pp. 81-112)

Summary of effect sizes from 12 meta-analyses assessing the influences of feedback

\begin{tabular}{|c|c|c|c|}
\hline Study & Context & $\begin{array}{l}\text { Number of } \\
\text { effects }\end{array}$ & $\begin{array}{l}\text { Effect } \\
\text { size }\end{array}$ \\
\hline $\begin{array}{l}\text { Skiba, Casey, and } \\
\text { Center (1985-1986) }\end{array}$ & $\begin{array}{l}\text { For special education } \\
\text { students }\end{array}$ & 35 & 1.24 \\
\hline Lysakowski and & & & \\
\hline Walberg (1982) & Cues, corrective feedback & 54 & 1.13 \\
\hline Walberg (1982) & $\begin{array}{l}\text { Cues, motivational } \\
\text { influences, and reinforcement }\end{array}$ & 19 & 0.81 \\
\hline $\begin{array}{l}\text { Tenenbaum and } \\
\text { Goldring (1989) }\end{array}$ & $\begin{array}{l}\text { Cues, participation, } \\
\text { reinforcement, feedback. } \\
\text { and correctives }\end{array}$ & 15 & 0.74 \\
\hline Rummel and & & & \\
\hline Feinberg (1988) & Extrinsic feedback rewards & 45 & 0.60 \\
\hline Yeany and Miller (1983) & $\begin{array}{l}\text { Diagnostic feedback in } \\
\text { science }\end{array}$ & 49 & 0.52 \\
\hline $\begin{array}{l}\text { Kluger and De } \\
\text { Nisi }(1996)\end{array}$ & Feedback & 470 & 0.38 \\
\hline $\begin{array}{l}\text { L'Hommedieu, Menges, } \\
\text { and Brinko (1990) }\end{array}$ & From student ratings & 28 & 0.34 \\
\hline Moin (1986) & Feedback & & 0.29 \\
\hline $\begin{array}{l}\text { Bangert-Drowns, } \\
\text { Kulik, Kulik, and }\end{array}$ & & & \\
\hline Morgan (1991) & From testing & 40 & 0.28 \\
\hline Kulik and Kulik (1988) & Immediate versus delayed & 53 & 0.28 \\
\hline Getsie, Langer, and & & & \\
\hline Glass (1985) & Rewards and punishments & 89 & 0.14 \\
\hline Wilkinson (1981) & Teacher praise & 14 & 0.12 \\
\hline
\end{tabular}

terkait dengan pujian, reward dan hukuman.Ringkasan efek ukuran yang terkait dengan efek feedback seperti tabel 2.

Pembelajaran terprogram, pujian, hukuman dan reward ekstrinsik adalah yang paling tidak efektif untuk meningkatkan prestasi (Tabel 2).Sesungguhnya, banyak pakar yang masih ragu tentang apakah reward juga bisa dianggap sebagai feedback.Deci, Koestner dan Ryan (1999) menggambarkan reward nyata (misalnya stiker, hadiah dsb) sebagai kontingensi utuk aktifitas dan bukan feedback karena mereka hanya mengandung sedikit informasi. Dalam meta analisis tentang efek feedback pada motivasi, para pakar tersebut menemukan adanya korelasi negatif antara reward ekstrinsik dan kinerja tugas (-0.34). reward nyata secara signifikan malah menurunkan motivasi intrinsik, khususnya untuk tugas yang menarik (-0.68)jika dibandingkan dengan tugas yang tidak menarik (0.18). Selain itu, jika feedback diberikan dalam sebuah pola yang terkontrol (misalnya menyatakan bahwa kinerja siswa adalah sesuatu yang memang "seharusnya" dilakukan), maka efek tersebut akan lebih buruk (-0.78). jadi, Deci dan kawan-kawan menyimpulkan bahwa reward ekstrinsik adalah negative karena reward-reward tersebut "melemahkan orang yang bertanggung jawab untuk memotivasi atau mengatur diri mereka sendiri”.

\section{SIMPULAN}

Feedback dalam perspektif teori behaviouristikdipandang sebagai penguatan (reinforcement). Feedback dalam perspektif teori kognitifberpandangan bahwa feedback berfungsi tidak hanya untuk memperkuat jawaban yang benar tetapi juga menjadi informasi korektif.Perspektif teori konstruktif, feedback terjadi dalam bentuk interaksi antara siswa dan aktifitas pemecahan masalah yang nyata dan sebagai sarana proses konstruktif. Feedback dalam perspektif teori regulasi diri memberikan penekanan pada pentingnya interaksi antara informasi feedback dan penerima serta memberikan penekanan pada keterlibatan aktif pebelajar untuk mencari petunjuk-petunjuk dan memonitor serta mengevaluasi performa mereka sendiri

Hasil kajian meta analisis penelitian tentang feedback dalam kelas berjumlah 196 penelitian dan 
Summary of effect sizes relating to feedback effects

\begin{tabular}{lcccc}
\hline Variable & $\begin{array}{c}\text { Number of } \\
\text { meta-analyses }\end{array}$ & $\begin{array}{c}\text { Number of } \\
\text { studies }\end{array}$ & $\begin{array}{c}\text { Number of } \\
\text { effects }\end{array}$ & $\begin{array}{c}\text { Effect } \\
\text { size }\end{array}$ \\
\hline Cues & 3 & 89 & 129 & 1.10 \\
Feedback & 74 & 4,157 & 5,755 & 0.95 \\
Reinforcement & 1 & 19 & 19 & 0.94 \\
Video or audio feedback & 1 & $9 !$ & 715 & 0.64 \\
Computer-assisted & & & & \\
$\quad$ instructional feedback & 4 & 161 & 129 & 0.52 \\
Goals and feedback & 8 & 640 & 121 & 0.46 \\
Student evaluation feedback & 3 & 100 & 61 & 0.42 \\
Corrective feedback & 25 & 1,149 & 1,040 & 0.37 \\
Delayed versus immediate & 5 & 178 & 83 & 0.34 \\
Reward & 3 & 223 & 508 & 0.31 \\
Immediate versus delayed & 8 & 398 & 167 & 0.24 \\
Punishment & 1 & 89 & 210 & 0.20 \\
Praise & 11 & 388 & 4,410 & 0.14 \\
Programmed instruction & 1 & 40 & 23 & -0.04 \\
\hline
\end{tabular}

Tabel 2: Hasil Penelitian Bentuk-Bentuk Feedback Pembelajaran

(Sumber:John Hattie and Helen Timperley. 2007.The Power of Feedback, Review of Educational Research , Vol. 77, No. 1, pp. 81-112)

6972 efek ukuran ditemukan rata-rata efek ukuran yang ada adalah 0.79 (dua kali efek ukuran). Terkait dengan rata-rata $0.79 \mathrm{ini}$, maka sintesisnya adalah feedback menempati peringkat 5 besar dari 10 pengaruh terbesar pada prestasi, bersamasama dengan pembelajaran langsung (0.93), pengajaran resiprokal (0.86), kemampuan kognitif awal siswa $(0,71)$ dan juga bisa dibedakan dengan pengaruh lainnya misalnya akselerasi (0.47), pengaruh sosio ekonomi $(0,44)$, pekerjaan rumah (0.41), penggunaan kalkulator $(0.24)$, pengurangan ukuran kelas (0.12), dan retensi satu tahun ke belakang (-0.12).

\section{DAFTAR RUJUKAN}

Andrew C. Butler, Jeffrey D. Karpicke, Henry L. Roediger, III. 2008. Correcting a Metacognitive Error: Feedback Increases Retention of Low Confidence Correct Responses. Journal of Experimental Psychology, Vol. 34, No. 4.

Andrew C. Butler, Jeffrey D. Karpicke, and Henry L. Roediger III. 2007. The Effect of Type
Karateristik feedback pembelajaran haruslah bersifat non evaluatif, suportif, tepat waktu, dan spesifik.Feedback pembelajaran dapat disajikan dalam bentuk informasi pada siswa sebagai respons untuk tindakan yang dilakukan oleh siswa. Feedback bisa diberikan dalam berbagai macam bentuk misalnya, verifikasi untuk akurasi jawaban, penjelasan tentang jawaban yang benar, petunjuk dan contoh yang dikerjakan dan dapat dilakukan kapanpun selama proses pembelajaran, misalnya setelah diberikannya jawaban, atau setelah jeda waktu tertentu.

and Timing of Feedback on Learning From Multiple-Choice Tests.Journal of Experimental Psychology, Vol. 13, No. 4.

Azevedo, R., \& Bernard, R. M. (1995).A metaanalysis of the effects of feedback in computer-based instruction.Journal of Educational Computing Research, 13(2). 
Bangert-Drowns, R. L., Kulik, C. C., Kulik, J. A.\& Morgan, M. T. (1991).The instructional effect of feedback in test-like events. Review of Educational Research, 61.

Birgit Harks, Katrin Rakoczy, John Hattie, Michael Besser And Eckhard Klieme.2014. The effects of feedback on achievement, interest and self-evaluation: the role of feedback's perceived usefulness. Educational Psychology, Vol. 34, No. 3.

Butler, R. (1987). Task-involving and ego-involving properties of evaluation: Effects of different feedback conditions on motivational perceptions, interest, and performance. Journal of Educational Psychology, 79(4), 47.

Carless, David. 2006. Differing perceptions in feedback process. Sudies in Higher Education Vol.13 No.2.

Cohen, V. B. (1985). A reexamination of feedback in computer-based instruction: Implications for instructional design. Educational Technology, 25(1).

Hattie, J and Timperley, H. 2007. The Power of Feedback.Review of Educational Research, Vol. 77, No. 1.

Hattie, J. and Mark Gan, 2011.Intruction Based on Feedback, inHanbook Research on Learning and Instrauction. Chapter 13.

Jared A chase, Ramona Houmanfaas. 2009. The Differential Effects of Elaboratif Feedback and Basic Feedback on Student Performance in a Modified, Perzonalized System of Instruction Course. Journal Behaviour Education. Vol.18.

Kulhavy, R. W., \& Stock, W. 1989. Feedback in written instruction: The place of response certitude. Educational Psychology Review, 1(4).

Kulhavy, R. W., \& Wager, W. 1993. Feedback in programmed instruction: Historical context and implications for practice. In J. Dempsey \& G. Ales (Eds.), Interactive instruction and feedback.Englewood Cliffs, NJ: Educational Technology Publications.

Kulik,J.A. \& Kulik, C.C. 1988.Timing of feedback and verbal learning. Review of Educational Research, 58(1).

Kluger, A.N. \& De Nisi, A. 1998. Feedback interventions: Toward the understanding of a double-edged sword. Current Directions in Psychological Science, 7.

Lepper,M.R.\&Chabay,R.W.1985. Intrinsic motivation and instruction:Conflicting views on the role of motivational processes in computer-based education. Educational Psychologist, 20(4).

Lia voerman dkk.2012.Types and frequencies of feedback interventions in classroom interaction in secondary education.Teaching and Teacher Education $\mathrm{xxx}, 1-9$ journal homepage: www.elsevier.com/locate/tate.

Marieke Thurlings, dkk. 2013.Understanding feedback: A learning theory perspective. Journal ho mepage: Computer\&Education9,115.www.elsevier. com/locate/EDUREV.

Marija Vojdanoska, Jacquelyn Cranney and Ben R,Newell. 2009. The Testing Effect: The Role of Feedback and Collaboration in a Tertiary Classroom Setting.Published online in Wiley Online Library (wileyonlinelibrary.com).

Mory, E. Holland . 2011. Feedback Research Rivisited. Handbook of Research for Educational Communication and Technologi, (AECT) T, Chapter 29.

Narciss, S., \& Huth, K. 2004. How to design informative tutoring feedback for multimedia learning. In H. M. Niegemann, D. Leutner, \& R. Brunken (Ed.), Instructional design for multimedia learning.Munster, NY: Waxmann.

Narciss, S. 2010. Feedback Strategies for Interactive Learning Tasks.Handbook of Research for Educational Communication and Technologi, (AECT) Tahun 2010, Chapter 11.

Paul C. Burnett.2010. Praise and Feedback in Primary Classroom: Teachers' and Student' Perspektives.Australian Journal of Educational. Vol.10.

Sichinga, K.T., Mfuni, J.H.C, Nenty, H.J., \& Chakalisa, P.2014. Factors Influencing quality of Feedback in Teaching in Botswana Senior Secondary Schools. International Journal of Research In Social Sciences, Vol. 4, No.1

Shute, Valerie.J. 2008. Focus on Formative Feedback, Review of Educational Research. Vol. 78, No. 1. 
Susanne Narciss dkk. 2014. Exploring feedback and student characteristics relevant for personalizing feedback strategies. journal homepage: Computers \& Education 71. www.elsevier.com/locate/compedu.
Susanne Narciss, 2010. Feedback Strategies for Interactive Learning Tasks. Handbook of Research for Educational Communication and Technologi, (AECT) Tahun 2010, Chapter 11. 